\title{
MERUBAH ANCAMAN BAHAYA LIMBAH CAIR INDUSTRI TAHU MENJADI PELUANG EKONOMI
}

\author{
Maharso, Hj.Darmiah, Zulfikar Ali As \\ Poltekkes Kemenkes Banjarmasin Jurusan Kesehatan Lingkungan Banjarbaru \\ Jl. H. Mistar Cokrokusumo No. 1A Kota Banjarbaru \\ e-mail : maharsom@gmail.com
}

\begin{abstract}
Abstrak : Changing the Threat of tofu Wastewater Hazardous to be Economical Oppurtunities. Wastewater from Tahu industry known as "whey" are offensive and be able to cause negative impact to the environment. This problem is caused by the characteristic of whey which is hot, acid, and containing much organic material. Because of this characteristic, their dissolve oxygen is also zero ppm. Measurement of tahu and tempe wastewater in Semanan, Jakarta Barat showed that the whey contains $1.324 \mathrm{mg} / \mathrm{l}$ of BOD5, $6.698 \mathrm{mg} / \mathrm{l} \mathrm{of}$ COD, $84,4 \mathrm{mg} / \mathrm{l}$ of NH4, $1,76 \mathrm{mg} / \mathrm{l}$ of nitrate and $0,17 \mathrm{mg} / \mathrm{l}$ of nitrite 1 ). The potential hazard of whey to aquatic life can be measured by counting the concentration of whey's parameter which be able to cause the death of tilapia (LC50), that is from $3,80 \%$ up to $11,5 \%$ at 24 hours exposure; $3,67 \%$ up to $14,30 \%$ at 72 hours exposure; and 3,38\% up to $12,10 \%$ at 72 hours exposure 2). On the other hand, Acetobacter can change sugar to be vinegar, with byproduct is film coat "nata" floating. Factors influencing Acetobacter growth are sources of Carbon and Nitrogen. Appropriate nutrient content will produce "rendemen nata" (de coco) maximum, that is up to $93,3 \% 3$ ). This study aims to know does the whey which is added by Acetobacter xylinum can produce nata de soya?. The result gave information that if into the whey added the Acetobacter (made from ripe pineapple) as a starter, and urea in acidic condition, would produce rendemen nata approximately $30 \%-40 \%$. 4).
\end{abstract}

Keywords: wastewater of tahu industry; nata de soya of whey

\begin{abstract}
Abstrak : Limbah cair industri tahu bersifat ofensif dan mampu memberikan akibat buruk pada lingkungan ambiennya. Hal itu dikarenakan karakteristik effluent limbah cair industri tahu yang panas, asam, dan mengandung bahan organik yang tinggi. Karena sifat inilah kandungan oksigen terlarutnya juga nol ppm. Hasil pengukuran parameter air limbah tahu dan tempe di daerah Semanan, Jakarta Barat menunjukkan kandungan BOD5 mencapai 1.324 $\mathrm{mg} / \mathrm{l}$, COD $6.698 \mathrm{mg} / \mathrm{l}, \mathrm{NH} 484,4 \mathrm{mg} / \mathrm{l}$, nitrat $1,76 \mathrm{mg} / \mathrm{l}$ dan nitrit $0,17 \mathrm{mg} / \mathrm{l} .1$ ). Potensi bahaya limbah ini terhadap kehidupan biota air dapat diukur dengan menghitung konsentrasi limbah cair industri tahu yang dapat menyebabkan kematian ikan nila (LC50), yaitu mulai dari 3,80\%-11,5\% pada pajanan 24 jam; 3,67\%-14,30\% pada pajanan 72 jam; dan 3,38\%-12,10\% pada pajanan 72 jam.2). Disisi lain bakteri Acetobacter mampu merubah gula menjadi asam cuka, dengan hasil sampingan berupa lapisan film nata terapung. Beberapa faktor yang mempengaruhi pertumbuhan Acetobacter adalah sumber Karbon, Nitrogen. Kandungan Nitrogen yang tepat akan menghasilkan rendemen nata (de coco) yang maksimal, yaitu sampai 93,3 \%.3). Tujuan penelitian ini untuk mengetahui apakah limbah cair tahu yang ditambahkan bakteri Acetobacter xylinum dapat menghasilkan nata de soya. Hasil percobaan memberikan informasi bahwa jika limbah cair tahu ditambahkan starter Acetobacter (yang dibuat dari buah nanas masak) dan pupuk urea dalam kondisi yang asam, akan menghasilkan rendemen nata sekitar 30\%-40\%. 4).
\end{abstract}

Kata Kunci: limbah cair industri tahu; nata de soya limbah tahu

\section{PENDAHULUAN.}

Dalam rangka menyambut hari lingkungan hidup sedunia tahun 2013 yang lalu, Jambi daily dalam salah satu artikelnya menyajikan hasil studi Kementerian Lingkungan Hidup (KLH) Tahun 2012. Publikasi Kementerian Lingkungan Hidup tersebut memberikan informasi bahwa Indeks Perilaku Peduli Lingkungan (IPPL) di Indonesia masih berkisar pada angka 0,57 (dari angka mutlak 1). Publikasi tersebut juga menyebutkan tentang perilaku konsumsi masyarakat dalam pemenuhan kebutuhannya, $49,3 \%$ berupa bahan ma- 
kanan (yang berasal dari luar daerahnya). 5)

Demikian halnya dengan tampilan rona lingkungan Indonesia saat ini. Pencapaian indeks kualitas lingkungan hidup di Indonesia pada angka 60,25 (tahun 2011); 61,07 (tahun 2010); dan 59,79 (tahun 2009). Sedangkan indeks kualitas lingkungan hidup di Kalimantan Selatan adalah 60,29 (tahun 2011, ranking 21), 58,24 (tahun 2010, ranking 21), 48,25 (tahun 2009, ranking 26). 6)

Permasalahan diatas menjadi relevan jika dikaitkan dengan pola konsumsi dan industri tahu yang meningkat dengan progresif. Untuk memproduksi tahu diperlukan sejumah air dengan perbandingan 1 bagian kedelai berbanding 45 bagian air, dan 96,66 \% air tersebut menjadi limbah cair (Whey). 7) Dalam waktu singkat lingkungan penerima limbah ini akan menjadi septik dan berbau. Hal itu dikarenakan limbah cair ini bersifat asam, mempunyai temperatur dan bahan organik yang tinggi, serta kandungan oksigen terlarut nol ppm. Hasil pengukuran parameter air limbah tahu dan tempe di daerah Semanan, Jakarta Barat menunjukkan kandungan $\mathrm{BOD}_{5}$ mencapai 1.324 $\mathrm{mg} / \mathrm{l}$, COD $6.698 \mathrm{mg} / \mathrm{l}, \mathrm{NH} 484,4 \mathrm{mg} / \mathrm{l}$, nitrat $1,76 \mathrm{mg} / \mathrm{l}$ dan nitrit $0,17 \mathrm{mg} / \mathrm{l}$. 8) Potensi bahaya limbah ini terhadap kehidupan biota air dibuktikan oleh Hardiono dkk dengan menghitung konsentrasi limbah cair industri tahu yang dapat menyebabkan kematian ikan nila (LC50), yaitu mulai dari 3,80\%-11,5\% pada pajanan 24 jam; 3,67\%-14,30\% pada pajanan 72 jam; dan 3,38\%-12,10\% pada pajanan 72 jam.2)

Apabila demikian besarnya potensi masalah yang dimbulkan oleh limbah cair industri tahu, muncul pertanyaan, apakah sebaiknya jangan lagi memproduksi tahu; atau adakah cara yang dapat mereduksi (kalau mungkin menghilangkan) potensi kerusakan yang dapat ditimbulkan oleh limbah cair tahu? Salah satu jawaban untuk mengatasi (paling tidak mengu- rangi) masalah limbah cair industri tahu adalah dengan mengolah kembali limbah tersebut sebagai bahan baku pembuatan nata. Nata adalah biomassa yang sebagian besar terdiri dari selulosa, berbentuk agar dan berwarna putih. Massa ini berasal pertumbuhan Acetobacter xylinum pada permukaan media cair yang asam dan mengandung gula. Selain dapat dimakan, nata ini bisa dipergunakan sebagai bahan baku kertas, bahan kosmetika, dan sebagainya.

Berdasarkan uraian pada latar belakang diatas, tampak bahwa limbah cair industri tahu bersifat ofensif dan mampu memberikan akibat buruk pada lingkungan ambiennya. Sementara sifat bakteri Acetobacter $s p$. mampu merubah kandungan bahan organik menjadi asam asetat dan nata. Maka pertanyaan penelitiannya adalah "apakah potensi bahaya limbah cair tahu dapat diubah menjadi nata sebagai bahan yang bernilai ekonomi?"

\section{METODE PENELITIAN}

Studi epidemiologi ini merupakan systematic review. Sumber data penelitian ini berasal dari literatur yang diperoleh melalui internet, penelitian yang relevan, baik penelitian penulis berupa hasil penelitian Jusman Nainggolan (Kajian Pertumbuhan Bakteri Acetobacter $s p$ ), Maharso (Kualitas Bakteriologis Nata De Soya Produksi Rumah Tangga Dari Air Limbah Industri Tahu), serta penelitian lain yang relevan.

\section{HASIL DAN PEMBAHASAN}

Teknologi pengolahan limbah cair tahu

1. Sistem penampungan (lagon) anaerob

Berdasarkan sifatnya, pengelolaan limbah cair secara biologis dapat bersifat aerob atau bersifat an-aerob. Proses biologis akan menurunkan kandungan polutan organik yang ada di dalam air limbah. Tetapi proses anaerob mempunyai efisiesi pengolahan hanya berkisar antara $50 \%$ $70 \%$ saja. 

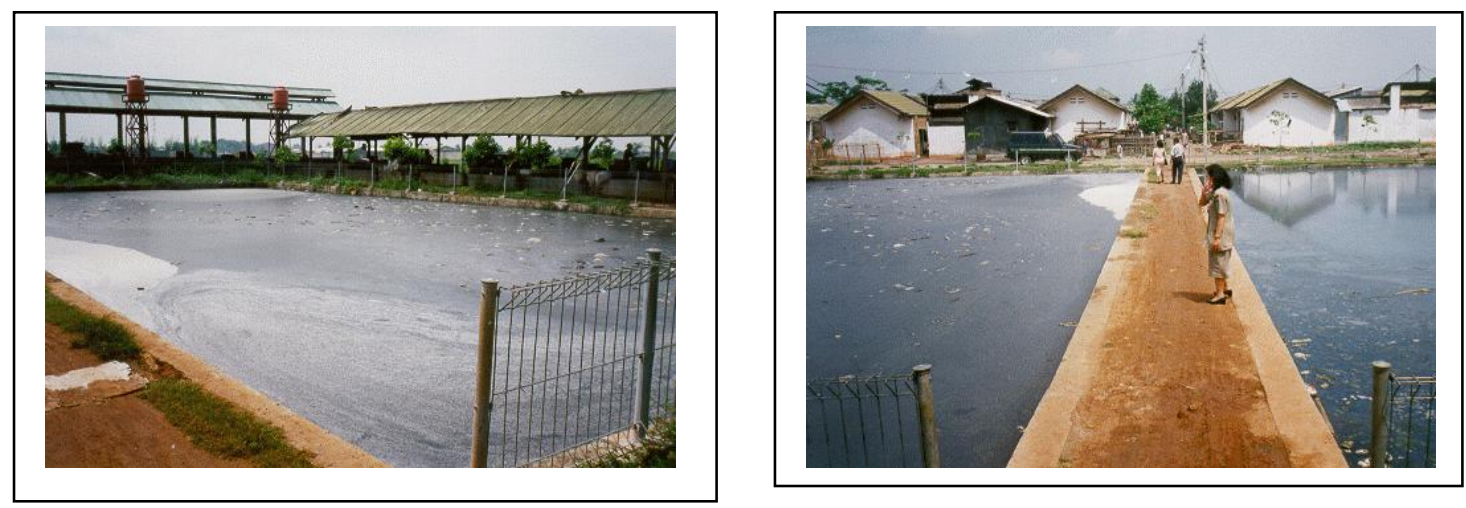

Gambar 1. IPAL Sistem Penampungan (lagon) Anaerob. 1)

2. Sistem kombinasi biofilter anaerobaerob

Cara pengolahan limbah cair Industri tahu juga dapat dilakukan dengan kombinasi proses pengolahan biologis anaerob dan aerob. Secara umum proses pengolahannya dibagi menjadi dua tahap yakni : 1) proses penguraian anaerob (Anaerobic digesting); dan 2) proses pengolahan lanjut, dengan sistem biofilter anaerob-aerob. Secara garis besar proses pengolahan air limbah industri tahu dan tempe ditunjukkan seperti pada Gambar 2

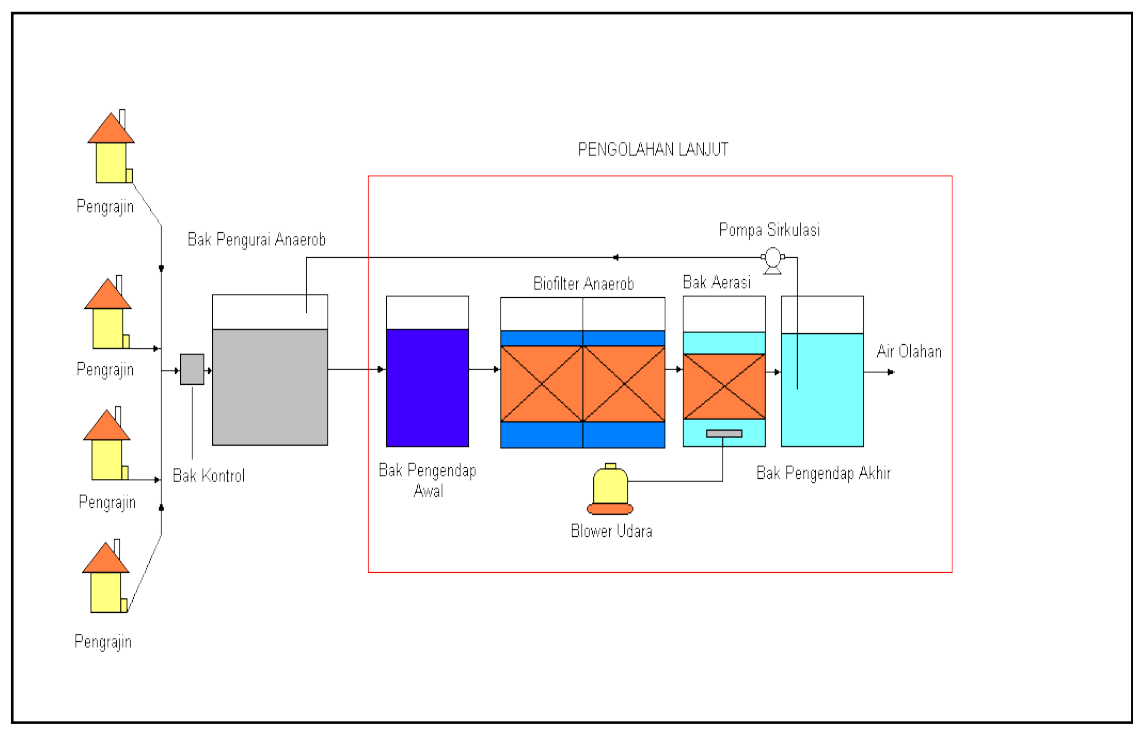

Gambar 2 : Diagram proses pengolahan air limbah industri tahu-tempe dengan sistem kombinasi biofilter "Anareb-Aerob" 1)

3. Sistem Fermentasi An-aerob fakultatif (pemanfaatan bakteri Acetobacter sp.)

Hipotesis sistem ini dibangun atas dasar teori diagram pada gambar 3 . Bahwa bakteri asetonik (bakteri yang memproduksi asetat dan $\mathrm{H}_{2}$ ) mempunyai hubungan simbiotik dengan bakteri metanogen (pembentuk gas methan). Di bawah kondisi tekanan $\mathrm{H}_{2}$ parsial yang relatif tinggi, pembentukan asetat berkurang dan subtrat dirubah menjadi asam propionat, asam butirat, dan etanol dari pada metan. Metanogen membantu menghasilkan ikatan hidrogen rendah yang dibutuhkan oleh bakteri asetogenik.

Bakteri asetogenik seperti Syntrobacter wolinii dan Syntrophomonas wolfei (McInernay et al., 1981) merubah asam lemak (seperti asam propionat, asam butirat) dan alkohol menjadi asetat, hidrogen, dan karbon dioksida, yang digunakan oleh bakteri pembentuk metan (metanogen). 


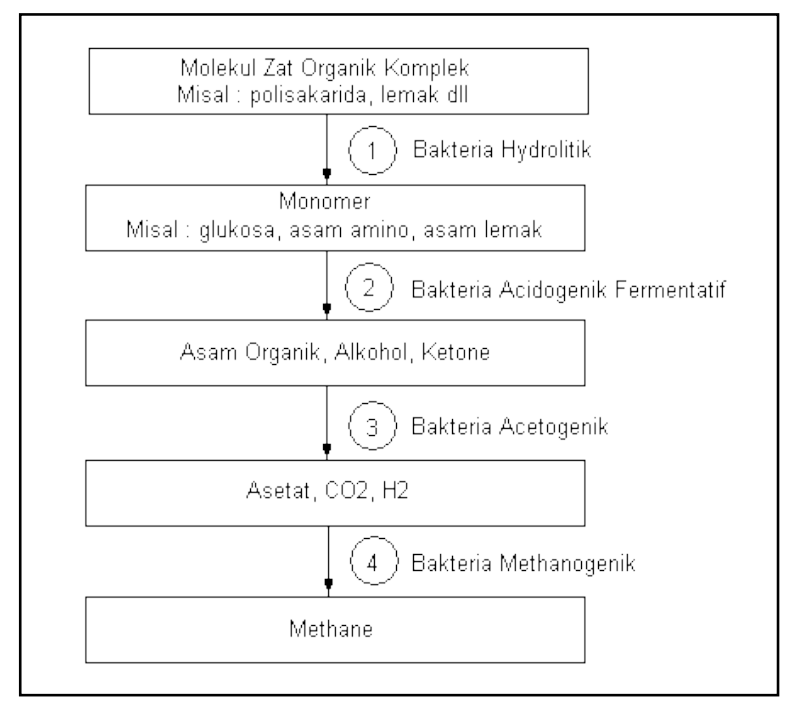

Gambar 3. Kelompok Bakteri Metabolik yang terlibat dalam penguraian limbah dalam sistem anaerobik

Kelompok ini membutuhkan ikatan hidrogen rendah untuk mengubah asam lemak; dan oleh karenanya diperlukan monitoring hidrogen yang ketat. 1)

Bakteri Acetobacter xylinum termasuk genus Acetobacter; bersifat gram negatif, tidak membentuk endospora, hidup bersifat aerob obligat, tidak melakukan fermentasi alkohol, berbentuk bulat lonjong sampai batang pendek; tumbuh baik pada ph 3,5-4,3 dan suhu $25-30{ }^{\circ} \mathrm{C}$, dapat mengoksidasi etanol dan menghasilkan asam asetat. Secara fisik bakteri Bakteri Acetobacter xylinum mampu mengoksidasi glukosa menjadi rantai atau polimer yang panjang yang disebut dengan polisakarida atau selulosa berupa serat-serat putih, yang terbentuk secara bertahap dari lapisan tipis pada awal fermentasi hingga mencapai ketebalan 12 mm pada akhir fermentasi, kemudian disebut sebagai nata yang termasuk metabolit sekunder. Selain metabolit sekunder, Acetobacter sp. juga menghasilkan metabolit primer berupa asam asetat, air dan energi yang digunakan kembali pada siklus metabolismenya . 8)

Air banyak digunakan sebagai bahan pencuci dan merebus kedelai untuk proses produksinya. Limbah yang dihasilkan juga cukup besar. Sebagai contoh limbah industri tahu tempe di Semanan,
Jakarta Barat kandungan BOD 5 mencapai $1324 \mathrm{mg} / \mathrm{l}$, COD $6698 \mathrm{mg} / \mathrm{l}$, NH 4 84,4 $\mathrm{mg} / \mathrm{l}$, nitrat $1,76 \mathrm{mg} / \mathrm{l}$ dan nitrit $0,17 \mathrm{mg} / \mathrm{l}$ (Prakarindo Buana, 1996). Jika ditinjau dari Kep-03/MENKLH/11/1991 tentang baku mutu limbah cair, maka industri tahu dan tempe memerlukan pengolahan limbah. 1) Banyaknya bahan organik yang terkandung dalam limbah cair tahu memberi peluang pemanfaatan bakteri Acetobacter sp. dalam pengolahan limbah cair produksi tahu.

Percobaan pemanfaatan acetobacter sp dalam pengolahan limbah cair tahu4)

Jika limbah cair tahu ditambahkan kedalamnya bakteri Acetobacter xynilum dengan perbandingan yang ideal (sekitar $10 \%$ ) akan menghasilkan produk metabolit primer berupa asam asetat, dan metabolit sekunder berupa lapisan selulosa yang mengapung, yang dikenal dengan nama pasar "nata" seperti terlihat pada gambar 4 .

Langkah-langkah percobaan dilakukan oleh Maharso dengan menambahkan Acetobacter ke dalam limbah cair industri tahu. Tahapan perlakuan dan hasil yang didapat pada setiap akhir tahapan dapat dilihat pada tabel 1. Sedangkan visualisasi nata de soya yang terbentuk seperti pada gambar 4 . 


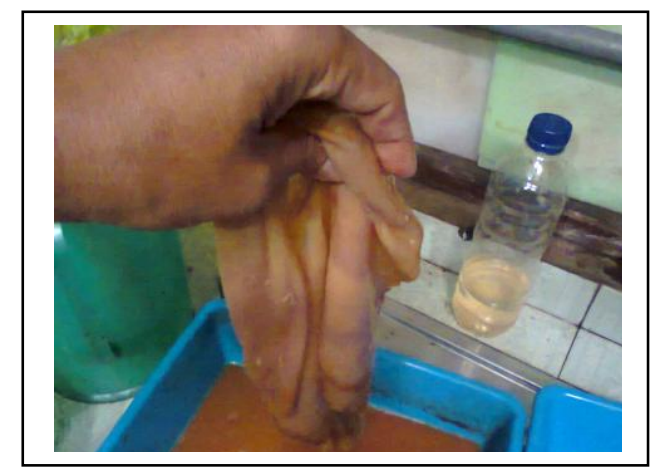

Gambar 4. Nata dari limbah cair industri tahu

Secara garis besarnya, proses dekomposisi bahan organik dapat terjadi melalui dua proses. Proses pertama adalah anaerobik yaitu apabila proses dekomposisi bahan organik terjadi tanpa suplai oksigen yang memadai. Proses kedua adalah proses aerobik, yaitu apabila proses penguraian bahan organik terjadi dalam lingkungan dengan suplai oksigen yang mamadai. Akan tetapi proses pembusukan bahan organik dapat pula terjadi secara bersamaan anaerobik dan aerobik. Contohnya pada kolam stabilisasi, akan terjadi dekomposisi anaerobik pada bagian dalam kolam dan dekomposisi aerobik pada permukaan kolam (sebatas kemampuan sinar matahari menembus permukaan kolam).

Tabel 1. Perlakuan pada Limbah Cair Tahu dengan Aplikasi Penambahan Acetobacter Sp.

\begin{tabular}{|c|c|c|c|}
\hline No & Tahapan & Perlakuan & Hasil \\
\hline 1. & $\begin{array}{l}\text { Pengolahan bahan } \\
\text { mentah (air limbah } \\
\text { tahu) }\end{array}$ & $\begin{array}{l}\text { - Air limbah tahu } \\
\text { - Starter } \\
\text { - Pupuk urea } \\
\text { - Cuka } \\
\text { - Gula pasir } \\
\text { - Dimasak sampai mendidih } \\
\text { - Disaring (memisahkan kotoran) } \\
\end{array}$ & $\begin{array}{l}\text { Media pertumbuhan } \\
\text { Acetobacter }\end{array}$ \\
\hline 2. & $\begin{array}{l}\text { Fermentasi bahan } \\
+ \text { starter }\end{array}$ & $\begin{array}{l}\text { - Bahan baku panas dituang dalam loyang' } \\
\text { ditutup dengan kertas koran } \\
\text { - Disimpan dalam suhu kamar, selama } 1 \text { hari } \\
\text { - Ditambahkan starter } \\
\text { - Difermentasikan selama 1-2 minggu }\end{array}$ & $\begin{array}{l}\text { Acetobacter dalam } \\
\text { media pertumbuan } \\
\text { (dari limbah cair } \\
\text { tahu) }\end{array}$ \\
\hline 3. & Akhir fermentasi & $\begin{array}{l}\text { - Nata dipisahkan dari media } \\
\text { - Dicuci dan direndam dengan air kran } \\
\text { selama } 3 \text { hari (pencucian dan penggantian } \\
\text { air setiap hari) }\end{array}$ & $\begin{array}{l}\text { - Asam asetat } \\
\text { - Nata de soya }\end{array}$ \\
\hline
\end{tabular}

Sumber : penelitian Maharso. 4)

Bahan organik tersusun oleh unsur kimia Karbon, Hidrogen, Oksigen, Nitrogen, Sulfur, dan Phosphat. Bentuk ikatan unsur kimia tersebut bisa dalam bentuk protein, lemak, atau karbohidrat. Apabila bahan tersebut terurai tanpa bantuan Oksigen, maka akan dihasilkan ikatan Karbon-Hidrogren, Hidrogen-Sullfida, dan Nitrogen-Hidrogen. Sedangkan produk akhir penguraian bahan organik secara aerobik dapat berupa ikatan Karbon-
Oksida, Hidrogen-Oksida. Dengan demikian produk akhir dari penguraian secara anaerobik relatif menjadi lebih berbahaya dibanding apabila penguraian terjadi secara aerobik. $\mathrm{CO}_{2}, \mathrm{SO}_{2}$, dan $\mathrm{NO}_{2}$, sebagai senyawa hasil penguraian aerobik ini akan segera menguap dan mengalami dispersi di udara.

Kumpulan mikroorganisme, umumnya bakteri, terlibat dalam transformasi senyawa komplek organik menjadi metan. 
Lebih jauh lagi, terdapat interaksi sinergis antara bermacam-macam kelompok bakteri yang berperan dalam penguraian limbah. Keseluruhan reaksi dapat digambarkan sebagai berikut (Polprasert, 1989, dalam Nusa Idaman) :1)

Senyawa Organik $\rightarrow \mathrm{CH}_{4}+\mathrm{CO}_{2}+\mathrm{H}_{2}+\mathrm{NH}_{3}$ $+\mathrm{H}_{2} \mathrm{~S}$

Meskipun beberapa jamur (fungi) dan protozoa dapat ditemukan dalam penguraian anaerobik, namun bakteri tetap merupakan mikroorganisme yang paling dominan bekerja didalam proses penguraian anaerobik. Sejumlah besar bakteri anaerobik dan fakultatif (seperti : Bacteroides, Bifidobacterium, Clostridium, Lactobacillus, Streptococcus) terlibat dalam proses hidrolisis dan fermentasi senyawa organik.

Ada empat grup bakteri yang terlibat dalam transformasi material komplek menjadi molekul yang sederhana seperti metan dan karbon dioksida. Kelompok bakteri ini bekerja secara sinergis. (Archer dan Kirsop, 1991; Barnes dan Fitzgerald, 1987; Sahm, 1984; Sterritt dan Lester, 1988; Zeikus, 1980), Dibawah kondisi tekanan $\mathrm{H}_{2}$ parsial yang relatif tinggi, pembentukan asetat berkurang dan subtrat dirubah menjadi asam propionat, asam butirat, dan etanol dari pada metan. Ada hubungan simbiotik antara bakteri asetonik dan metanogen. Metanogen membantu menghasilkan ikatan hidrogen rendah yang dibutuhkan oleh bakteri asetogenik.

1. Kekuatan dan kelemahan proses anaerobik

Ir. Nusa Idaman Said, M.Eng. dan Ir. Arie Herlambang, M.Si. berpendapat bahwa berdasarkan penjelasan Letingan, Sahm, Sterritt dan Lester, serta Switzenbaum beberapa keunggulan proses anaerobik dibandingkan proses aerobik adalah sebagai berikut : 1)

- Proses anaerobik dapat segera menggunakan $\mathrm{CO}_{2}$ yang ada sebagai penerima elektron. Proses tersebut tidak membutuhkan oksigen dan pemakaian oksigen dalam proses penguraian limbah akan menambah biaya pengoperasian.

- Penguraian anaerobik menghasilkan lebih sedikit lumpur 3-20 kali lebih sedikit dari pada proses aerobik), energi yang dihasilkan bakteri anaerobik relatif rendah. Sebagian besar energi didapat dari pemecahan substrat yang ditemukan dalam hasil akhir, yaitu $\mathrm{CH}_{4}$. Dibawah kondisi aerobik 50\% dari karbon organik dirubah menjadi biomassa, sedangkan dalam proses anaerobik hanya $5 \%$ dari karbon organik yang dirubah menjadi biomassa. Dengan proses anaerobik satu metrik ton COD tinggal $20-150 \mathrm{~kg}$ biomassa, sedangkan proses aerobik masih tersisa 400 - $600 \mathrm{~kg}$ biomassa (Speece, 1983; Switzenbaum, 1983).

- Proses anaerobik menghasilkan gas yang bermanfaat, metan. Gas metan mengandung sekitar $90 \%$ energi dengan nilai kalori $9.000 \mathrm{kkal} / \mathrm{m}^{3}$, dan dapat dibakar ditempat proses penguraian atau untuk menghasilkan listrik. Sedikit energi terbuang menjadi panas (3-5\%). Produksi metan menurunkan BOD dalam penguraian lumpur limbah.

- Energi untuk penguraian limbah kecil.

- Penguraian anaerobik cocok untuk limbah industri dengan konsentrasi polutan organik yang tinggi.

- Memungkinkan untuk diterapkan pada proses Penguraian limbah dalam jumlah besar.

- Sistem anaerobik dapat membiodegradasi senyawa xenobiotik (seperti chlorinated aliphatic hydrocarbons seperti trichlorethylene, trihalomethanes) dan senyawa alami recalcitrant seperti liGnin.

Selanjutnya Ir. Nusa Idaman Said, M.Eng. dan Ir. Arie Herlambang, M.Si. menjelaskan beberapa kelemahan penguraian anaerobik, yaitu :

- Lebih Lambat dari proses aerobik

- Sensitif oleh senyawa toksik

- Start up membutuhkan waktu lama

- Konsentrasi substrat primer tinggi

2. Nata de Soya dari limbah cair tahu

Pada umumnya konsentrasi ion hidrogen buangan industri tahu ini cenderung bersifat asam. Komponen terbesar dari limbah cair tahu yaitu protein $(\mathrm{N}$ total) sebesar 226,06 sampai $434,78 \mathrm{mg} / \mathrm{l}$. sehingga masuknya limbah cair tahu ke lingkungan perairan akan meningkatkan total nitrogen di peraian tersebut.1) 
Nata adalah biomassa yang berasal dari pertumbuhan Acetobacter xylinum pada permukaan media cair yang asam dan mengandung gula. Nata yang dibuat dari bahan baku air kelapa lebih populer dibanding nata yang dibuat dari limbah cair pengolahan tahu (whey tahu). Bentuk, warna, tekstur dan rasa kedua jenis nata tersebut tidak jauh berbeda. Pembuatan nata tidak sulit, dan biaya yang dibutuhkan juga tidak banyak. Usaha pembuatan nata ini merupakan alternatif usaha yang cukup menjanjikan (prospektif). Kata Nata berasal dari bahasa Spanyol, natare yang berarti krim.

Selulosa mikrobial adalah senyawa kimia organik yang diproduksi oleh mikroorganisme tertentu, bakteri yang paling terkenal produktivitasnya adalah Acetobacter xyllinum. Bakteri ini tumbuh secara alami pada limbah air kelapa, sari bunga, madu, dan kulit luar buah-buahan seperti nenas matang. Selain memproduksi nata, Acetobacter xyllinum juga memiliki kemampuan mengubah etanol menjadi asam asetat (cuka). Acetobacter juga mampu menghidrolisis sukrosa menjadi glucosa dan sebuah fruktosa. Jenis gula (sukrosa, glukosa, fruktosa) mempunyai pengaruh yang berbeda-beda terhadap pembentukan etanol dan asam laktat, namun konsentrasi gula secara individual hanya berpengaruh kecil terhadap rasa. Media-media yang mengandung gula adalah bahan baku pembuatan nata, dan berdasarkan jenis medialah nama nata diberikan misalnya Nata De Coco dari media air kelapa, Nata De Soya dari media susu kedelai atau ampas pabrik tahu, Nata De Cassava dari media ampas pabrik tapioka. Nata De Molase dari media limbah cair tebu, nata de tomato, nata de pina, nata de melo, nata de leri, dan sebagainya.

Pada percobaan pengolahan limbah cair tahu dengan cara memanfaatkannya sebagai bahan baku pembuatan nata de soya, dan starter Acetobacter xyllinum yang dibuat dari buah nanas masak diperoleh hasil lapisan nata setebal sekitar 10-12 $\mathrm{mm}$ dan rendemen sebanyak sekitar 30-40\%. Mengingat proses fermentasi memerlukan waktu 1-2 minggu, maka dapat diperkirakan proses fermentasi tersebut telah juga menurunkan nilai BOD.4) Dengan demikian terjadi reduksi bahan (limbah cair tahu) baik kuantitasnya maupun parameter pencemar lainnya.

\section{KESIMPULAN DAN SARAN}

\section{Kesimpulan}

1. Limbah cair industri tahu berpotensi merusak lingkungan. Hal itu dikarenakan limbah cair ini bersifat asam, mempunyai temperatur dan bahan organik yang tinggi, serta kandungan oksigen terlarut nol ppm.

2. Karakteristik limbah cair tahu tersebut banyak Nitrogen, Karbon, dan Hidrogen. Pada perlakuan yang tepat bahan ini dapat djadikan bahan baku untuk menghasilkan energi (gas methan) dan selulosa berupa serat biomassa (nata).

3. Baik gas methan maupun serat biomassa merupakan komoditas yang bernilai ekonomi, baik sebagai sumber energi alternatif $\left(\mathrm{CH}_{4}\right)$ maupun sebagai bahan baku makanan ringan pembuatan kertas dan bahan kosmetika (nata).

\section{Saran}

1. Agar terus dikembangkan sistem pengolahan limbah cair tahu, baik untuk memperoleh energi (gas methan) maupun biomassa, yang keduanya mempunyai nilai ekonomi.

2. Agar dilakukan penelitian yang sejenis dengan maksud mengukur efisiensi reaktor atau proses fermentasi bagi penurunan parameter pencemar dari limbah cair tahu.

\section{DAFTAR PUSTAKA}

1. Ir. Nusa Idaman Said, M.Eng. dan Ir. Arie Herlambang, M.Si.; Teknologi Pengolahan Limbah Tahu-Tempe Dengan Proses Biofilter Anaerob Dan Aerob; BPPT; 18 des 2012

2. Hardiono, Rahmawati, Uji Toksisitas Limbah Tahu Terhadap Ikan Nila (Oreochromis niloticus) di Banjar-baru, Risbinakes, Poltekkes Kemen-kes Banjarmasin, 2013

3. Payung Layuk, H. Salamba, R. Djuri, Perbaikan Teknologi Pengolahan Nata De Coco Di Tingkat Petani (Studi Kasus Di Lokosi Primatani Desa Ongkaw 
Minahasa Selatan); Balai Pengkajian Teknologi Pertanian (BPTP) Sulawesi Utara; Seminar Regional Inovasi Teknologi Pertanian, mendukung Program Pembangunan Pertanian Propinsi Sulawesi Utara; 2007

4. Maharso, Kualitas Bakteriologis Nata De Soya Produksi Rumah Tangga Dari Air Limbah Industri Tahu, Penelitian PNBB, Poltekkes Kemenkes Banjarmasin, 2013

5. http://jambidaily.com/v3/advertorial \$3782-menteri-lingkungan-hidup-ajakubah-perilaku-dan-pola-konsumsiuntuk-selamatkan-lingkungan, 2013

6. Edi Sampana, SKM., M.Kes. Ubah Perilaku dan Pola Konsumsi untuk Cegah 'Global Warming', Seminar Nasional Kesehatan Lingkungan Banjarbaru, 22 Juni 2013
7. Nusa Idaman Said, Haryoto Indriatmoko, Nugro Raharjo, Arie Herlambang; Teknologi Pengolahan Limbah Tahu-Tempe Dengan Proses Biofilter Anaerob Dan Aerob; Kelompok Teknologi Pengelolaan Air Bersih dan Limbah Cair, Direktorat Teknologi Lingkungan Kedeputian Bidang Teknologi Informasi, Energi dan Material; Badan Pengkajian dan Penerapan Teknologi, 18 desember 2012; Jl. M.H. Thamrin No. 8, Jakarta Pusat

8. Jusman Nainggolan, Kajian Pertumbuhan Bakteri Acetobacter sp. Dalam Kambucha-Rosela Merah (Hibiscus sabdariffa) Pada Kadar Gula Dan Lamanya Fermentasi Yang Berbeda, Tesis, Sekolah Pascasarjana Universitas Sumatera Utara, Medan, 2009 